\title{
Mast cell concentration and skin wound contraction in rats treated with Ximenia americana $L^{1}$
}

\author{
José de Castro Souza Neto Junior', Lígia Reis de Moura Estevão", Liriane Baratella-Evêncio"', \\ Marcela Gabriela Feitosa Vieira'v , Ricardo Santos Simões ${ }^{\vee}$, Rinaldo Florencio-Silvavı, Luís Evêncio-

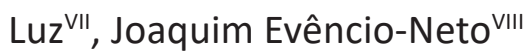

'Fellow PhD degree, Postgraduate Program in Animal Bioscience, Department of Mor-phology and Animal Physiology, Universidade Federal do Rio Grande do Norte (UFRN), Recife-PE, Brazil. Technical procedures; acquisition, analysis and interpretation of data; manuscript writing

"Fellow PhD degree, Postgraduate Program in Animal Bioscience, Department of Morphology and Animal Physiology, Universidade Federal Rural de Pernambuco (UFRPE), Recife-PE, Brazil. Acquisition, analysis and interpretation of data; technical procedures

'"'Associate Professor, Histology Division, Department of Histology and Embryology, Uni-versidade Federal de Pernambuco (UFPE), Brazil. Scientific, intellectual and design of the study; manuscript preparation; critical revision

IFellow PhD degree, Postgraduate Program in Animal Bioscience, Department of Morphology and Animal Physiology, UFRPE, Recife-PE, Brazil. Histopathological examinations, acquisition of data.

${ }^{\vee}$ PhD, Clinics Hospital, Faculdade de Medicina da Universidade de São Paulo (FMUSP), Brazil. Interpretation of data, manuscript writing.

VIFellow PhD degree, Postgraduate Program in Morphology, Department of Morphology and Genetics, Universidade Federal de São Paulo (UNIFESP), Brazil. Analysis and interpretation of data, manuscript writing.

VIIAssociate Professor, Microbiology Division, Department of Biology, Universidade Feder-al do Piauí, Picos-PI. Brazil. Conception and design of the study, critical revision.

VIIIProfessor, Anatomy Division, Department of Morphology and Physiology, UFRPE, Recife-PE, Brazil. Conception and design of the study, manuscript writing, critical revision, final approval

\section{Abstract}

Purpose: To evaluate wound contraction and the concentration of mast cells in skin wounds treated with wild plum (Ximenia americana) essential oil-based ointment in rats.

Methods: Sixty rats were submitted to two cutaneous wounds in the thoracic region, on the right and left antimeres. Thereon, they were divided into three groups: GX (wounds treated once a day with hydro alcoholic branch extract of Ximenia amerlcana), GP (wounds that received vehicle), and GC (wounds without product ap-plication). Wounds were measured immediately after the injury as well as 4, 7, 14 and 21 days post-topical application of the extract. At these days, five rats from each group were euthanatized. Thereafter, samples were fixed in $10 \%$ formalde-hyde and processed for paraffin embedding. Sections were stained with H.E, Masson's Trichrome and toluidine blue for morphological, morphometrical and histopathological analysis, under light microscopy. The degree of epithelial con-traction was measured and mast cell concentrations were also evaluated with an image analyzer (Image Pro-plus ${ }^{\circledR}$ software).

Results: The extract treated group showed lower mast cell concentrations in the 4th day of lesion, as compared to $G P(G X<G P=G C, p=0.029)$, as well as with increased con-traction at $7^{\text {th }}$ and $14^{\text {th }}$ days, respectively $\left(7^{\text {th }}\right.$ and $14^{\text {th }}$ days, $\left.G X>G P=G C ; p<0.05\right)$.

Conclusion: Ointment containing $10 \% X$. americana induces a decrease in mast cell concen-tration, at the beginning of the healing process, and promotes early skin wound contraction in rats.

Key words: Wound Healing. Phytotherapy. Mast Cells. Skin. Rats. 


\section{Introduction}

Studies have shown that there is an enormous biodiversity of plants species in caatinga, an ecoregion in northeast Brazil, which is a potential source of new natural products, among which are the Ximenia americana ( $X$. americana), popularly known as tallow wood, yellow plum, wild plum or sea lemon. This specie has been shown to have healing power, due to its considerable amounts of bioactive compounds, as well as antioxidant activity, antioxidant enzymes and tannins, flavonoids and alkaloids ${ }^{1,2}$. According to Souza et $a l .^{3}$ stem spraying powder is used in popular medicine for ulcer healing, antiinflammatory, such as depurative, menstrual regulator and gastric upset. Infusion of flowers is used to decrease diarrhea with blood. It is also used in insect bites, antipyretic activity and epidermal problems ${ }^{4}$.

The antitumor activities of $X$. americana were reported by Voss et al. ${ }^{5}$. Asres et al. ${ }^{6}$ showed that $X$. americana stem bark extract has antiviral activity against human immunodeficiency virus type 1 (HIV1) and type 2 (HIV-2), as well as antimicrobial activity against Enterococcus faecalis, Streptococcus pyogenes, Staphylococcus aureus and fungal resistance against Candida albicans ${ }^{7}$. Nevertheless, it was not found studies describing mast cells and cicatrization associate to $X$. americana extract.

Mast cells are derived from the myeloid stem cell and play an important role in the healing process. They are predominantly found in the dermis near to the vascular tissue, the basement membrane of endothelial cells and nerves ${ }^{8}$. They exhibit cytoplasmic granules containing histamine, serotonin, tryptase and various cytokines -tumor necrosis factor, interleukin-4, fibroblast growth factors and epithelial growth factors- are able to stimulate the proliferation of endothelial cells, epithelial and fibroblasts ${ }^{8}$. They have the function of helping the immune defense mechanism, acting as body guards, being involved in inflammatory and hypersensitivity reactions and local immune responses ${ }^{9}$. These cells participate in different phases of healing as in the control of the inflammatory response in epithelialization and revascularization of injured tissue, in the deposition of temporary connective tissue and subsequent remodeling of the conjunctiva matrix ${ }^{10}$.

The role of mast cells in healing has been widely discussed in the scientific community in recent years. Different scientific studies confirm the participation of these cells effectively at all stages of healing ${ }^{11,12}$. This study aimed to quantify the mast cells in different stages of healing and correlate them with the degree of contraction of cutaneous wounds in rats treated with $10 \% X$. americana extract.

\section{- Methods}

The study protocol was approved by the Animal Ethics Committee of the Universidade Federal Rural de Pernambuco (UFRPE) (process no 088/2015).

Sixty adult male rats (Rattus norvegicus albinus) weighing approximately $300 \mathrm{~g}$ were obtained from the Department of Morphology and Physiology, UFRPE. The animals were housed in individual cages with commercial chow (Presence ${ }^{(r)}$, Purina) and maintained at 23-25드, under a 12 hours light/dark cycle, at the Pharmacy Department, UFPE, with water ad libitum,

After one week of adaptation, the animals were anesthetized with a combination of $2 \%$ xylazine hydrochloride $(3 \mathrm{mg} / \mathrm{kg})$ and $10 \%$ ketamine hydrochloride $(10 \mathrm{mg} / \mathrm{kg})$, administered intramuscularly ${ }^{13}$. The dorsal fur of the animals was trichotomized in the thoracic region and antisepsis was performed 
with topic application of $2 \%$ chlorhexidine. Then, with the aid of a $0.8 \mathrm{~cm}$ diameter dermatological punch, two surgical wounds were made in each animal. The incisions were carried out in such a way that the skin and subcutaneous tissue were included, being exposed the adjacent muscular fascia, one in the right antimer and the other in the left antimer (the area was initially marked by the dermatological punch). With a surgical blade and blunt scissors, incisions were performed in skin and subcutaneous tissue. The tissue was dissected and removed leaving exposed the adjacent fascia. Immediately after surgical excision the wounds received daily topical applications of Lanette base cream (vehicle) or branch extract of $X$. americana.

The experimental design was completely randomized and equally divided in three groups (20 animals each one), as follow: GX - wounds treated with $10 \%$ branch extract of $X$. americana; GP - wounds treated with vehicle; GC - animals with untreated wounds. Each wound was treated immediately after surgery, and daily as described by the following methodology: the treated group, daily topical application of $X$. americana branch extract, in sufficient quantity to cover the wound; default group, daily topical application of Lanette base cream and control group, received only management similar to the other groups, but the wounds were not treated. Five animals from each group were evaluated on 4, 7, 14 and 21 days after surgery. Euthanasia was performed by deepening of anesthesia (xylazine - $20 \mathrm{mg} / \mathrm{Kg}$ and ketamine - $100 \mathrm{mg}$ / $\mathrm{Kg}$, intramuscularly).

\section{Preparation of the $X$. americana branch extract}

The tree of the $X$. americana were collected in time of drought time (may 2010), at the Araripe region - Pernambuco, where it occurs in natural conditions. The exsicata is cataloged in the Herbarium of the Brazilian Agricultural Research Corporation - "Herbário da Empresa Brasileira de Pesquisa Agropecuária" EMBRAPA under the registration number $n^{\circ}$ 5903, coordinates: (Latitude: -7.8825, Longitude: -40.0817, \pm 56078).

The hydroalcoholic of $X$. americana was produced from the branches. Bark and wood were ground in an electric grinder with fine sieve of one millimeter. The resulting powder was weighed and its mass was added to the $70 \%$ hydroalcoholic solution in the proportion of 1:3 of powder and then packaged in amber vial closed to minimize evaporation. After 24 hours the material was placed in routeevaporator for phase separation and obtaining the extract, produced at the Natural Products Laboratory of Bioactive UFRPE.

The extracts were applied on the base plate of silica and placed to dilute in chromatographic tank with diluents in the following proportion: $X$. americana; AcOEt; MetOH (5:4:1). The plates were observed in UV chamber at wavelengths $254 \mathrm{~nm}$ and 365 $\mathrm{nm}$ and their visible spectra were drawn. Then, the revealing was sprayed on the plate and heated at $50^{\circ} \mathrm{C}$ until the appearance of colored bands that have been visualized in visible light and ultraviolet.

The $X$. americana extract was added to Lanette base for the production of an $10 \%$ anionic cream used in the experiment.

\section{Morphology and morphometry}

On 4th, 7th, 14th and 21st days after surgery, the wounds of each group were measured with the aid of a caliper graph (King Tools). The calculation of the average degree of contraction (C) was expressed as percentuals, being:

$$
C=[(A 0-A i) / A 0] .100 \text {, }
$$

Where $A O$ is the initial area of $\mathrm{mm}$ the wound (day 0 ) and $A i$ is the area of the 
wound in the 4th, 7th, 14th and 21st days postoperatively. On day 0 (day of surgery) and 4th, 7th, 14th and 21st days after surgery all wounds from each group were evaluated and measured with a caliper rule. For wound area calculation, the largest and the smallest diameters were observed. From these data, the wound area was obtained using the mathematical equation: $A=\pi$.R.r, in which $A$ represents the area; $R$, the largest radius; and $r$, the smallest radius of the wound. The contraction degree calculation was expressed in percentages using the mathematical equation: $100 \times$ (Wo - Wi) $\div$ Wo, in which Wo is the initial wound area (day 0 ) and $\mathrm{Wi}$ is the wound area on the 4th, 7th, 14th and 21st post-operative day as described by Ramsey et al. ${ }^{14}$.

Afterwards, with the animals anesthetized as previously described, each surgical wound were dissected with 0.5 $\mathrm{cm}$ margin of integral whole skin on the perimeter of the lesion and depth to the dorsal muscular fascia. Then, the collected wound specimens were processed for histological and morphometrical analysis.

\section{Histological analysis}

After this, the fragments were fixed in $10 \%$ formaldehyde, tissue samples were dehydrated in increasing concentrations of ethyl alcohol and cleared in xylene. Samples were then processed for paraffin inclusion. For each animal cuts were made in the middle region of the flap sections longitudinal samples $(5 \mu \mathrm{m})$ were obtained parallel to the greater axis of fragments and stained with Hematoxylin and Eosin (H.E), Masson's Trichrome and Toluidine Blue for morphological and morphometric analysis.

\section{Morphometric analysis}

Six images of each slide was obtained always immediately below the crust, with the aid of a trinocular biological microscope (NIKON 50i) under x400 magnification and adjusted to a capturing image system. Quantification of mast cells was performed in the center of the lesion in an area of $0.66 \mathrm{~mm}^{2}$ (imaging), with the aid of an image analyzer (by Image Proplus ${ }^{\circledR}$ software) in a Windows operational system.

\section{Statistical analysis}

Statistical analysis was carried out from data obtained of variables: wound contraction and quantity of mast cells. Initially an exploratory analysis with the aim of verifying the distribution of frequency for the categorical variables, and descriptive measures for the numeric variables was made. Each variable was analyzed within each day and between the days by comparing groups (GTX, GP e GC) through non-parametric Kruskal-Wallis test, between each variable and among the 4, 7, 14 days for wound contraction and among 4, 7, 14 e 21 days for mast cells quantification. In the cases that significant differences occurred among the groups or among the days, the Dunn test was applied. For all tests the significance level was set at $5 \%(p<0.05)$. The statistical analysis was carried out by using the Statistical Package for the Social Sciences - SPSS $20^{\circledR}$ software.

\section{- Results}

Macroscopically, the wounds appeared clean, without signs of irritation, discharge and bleeding throughout the experiment. All groups presented a fibrin-leukocyte layer. However, the layer was more evident in the group treated with $X$ from the 3rd PO day, progressing to a thick crust, dark and firm. The GC and GP groups showed a crust with a thin layer unsteadily and yellowish color (Figure 1). 


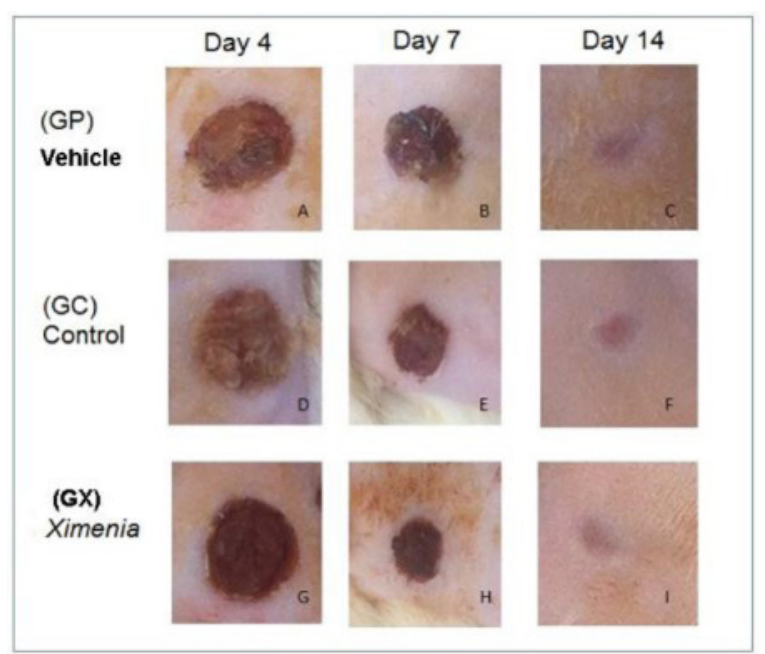

Figure 1 - Macroscopic aspects of lesions in groups $(\mathrm{GX}, \mathrm{GP}, \mathrm{GC})$. Note the crust thickness in the figure (A) from the $4^{\text {th }}$ day when compared with the figure $(G)$. In the $7^{\text {th }}$ day notice the diameters of figures $(B, E)$ higher than the figure $(H)$. Observe a darker color in the wounds $(G, H)$ when compared with the figures ( $A, B, D$ and $E$ ). In $14^{\text {th }}$ day, we observe the figure (I) with a smaller area of healing when compared with the figures (C, F).

Byobserving the evolution of reepithelialization it was noted that there was contraction in all groups from the 4th PO day, however, with a significant increase in the level of contraction on post operative days 7 and 14 in the GX compared to other groups GP and GC $(p<0.01)$ (Figure 2).

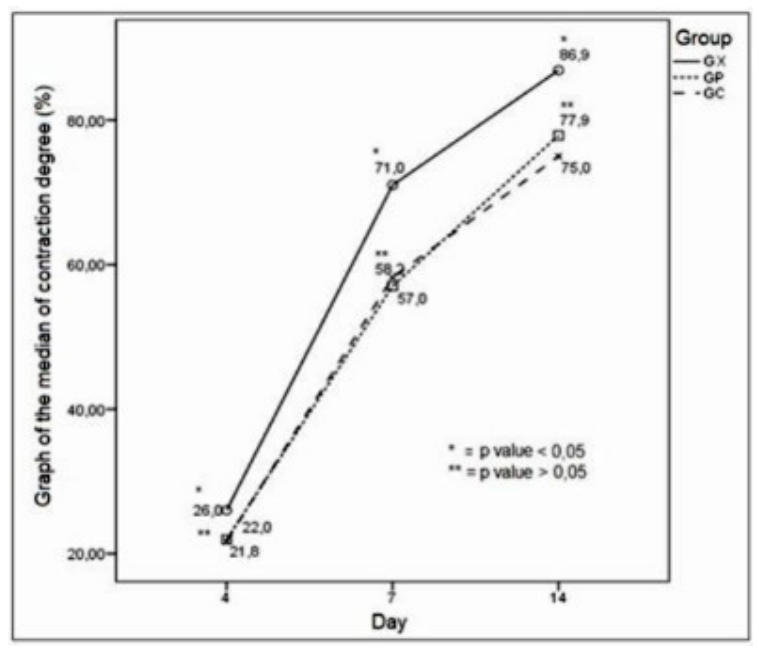

Figure 2 - Graph of the median contraction degree from the wounds of groups (GX, GP and GC), on days 4,7 and $14 \mathrm{PO}$.
Quantification of mast cells in granulation tissue showed a significantly lower number of cells in the group treated with $X$ on the 4th $P O$ day when compared to other groups (GX $<\mathrm{GP}, \mathrm{p}=0.029 ; \mathrm{GX}<\mathrm{GC}, \mathrm{p}=0.016$ ). There was no statistical difference between the GP and GC ( $p=0.071)$ (Figure 3). However, we note increased mast cell degranulation in the group treated with $X$. americana, on the 4th PO day, when compared to the other groups (Figure 4).

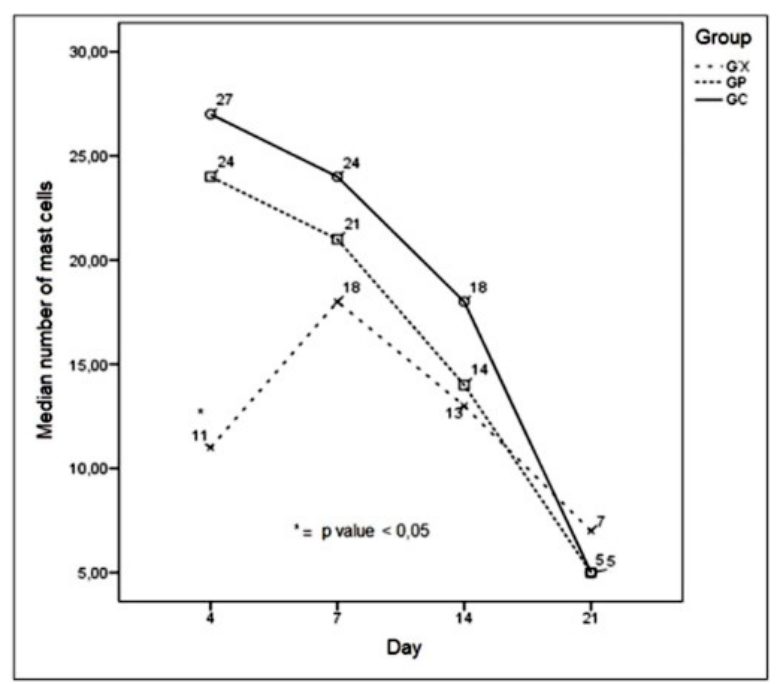

Figure 3 - Graph of median mast cells number. Note the difference of the group (GX) on day 4 when compared to others groups (GP and GC).

Morphologically, we observed higher concentrations of fibroblasts, blood vessels and polymorphonuclear cells in the 4th and 7th PO day in the GX when compared to the other groups. By Masson's Trichrome, we visualize larger amounts of collagen fibers in all groups, however, in the group treated with $X$. americana the fibers showed denser from the 4 th $(P O)$ and quite organized in the 14th $P O$, when compared to GC and GP. 

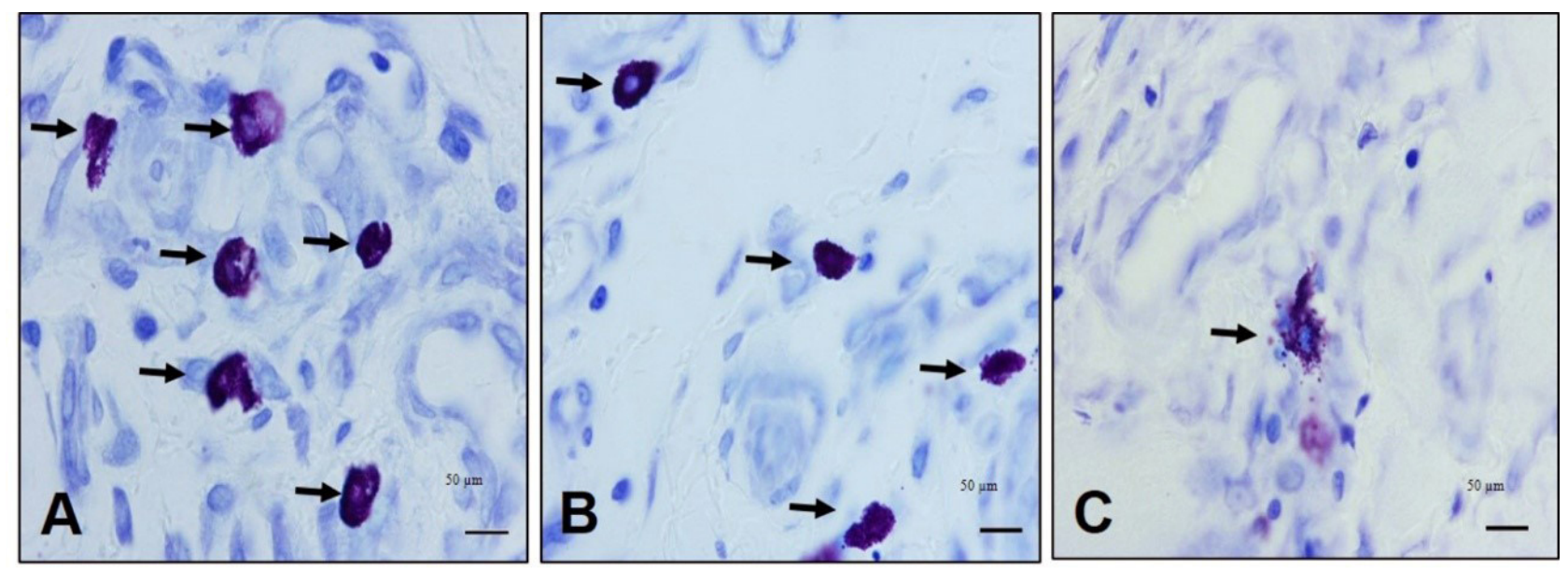

Figure 4 - Photomicrographs of skin wounds in rats on the $4^{\text {th }}$ day after surgery. GC (A), GP (B) and GX treated group (C). Note numerous mast cells in the groups (A, B) when compared to group (C) (arrows). Observe in (C) the degranulation of mast cells with the presence of granule (arrow). Staining: Toluidine Blue. Scale bar: $50 \mu \mathrm{m}$.

\section{- Discussion}

Studies of ethno biological nature favor the rescue of popular culture, preventing important cultural and biological information from being lost over time ${ }^{18}$. Ethnopharmacology of medicinal plants of northeastern Brazil refers to the $X$. americana having uses attributed to healing properties such as wound healing ${ }^{1}$.

The contraction of the wound is considered as a reference of healing capacity. In other words, the better the healing, the faster and increased the degree of contraction ${ }^{12}$. Those responsible for this phenomenon are the myofibroblasts, which provided large amounts of actin filaments, are responsible for this activity, mainly in second intention healing ${ }^{15}$.

Marinho et al. ${ }^{16}$ say there is no favoritism in the contraction of skin wounds in goats after the use of hydroalcoholic extract $10 \% X$. americana. Those results are explained in the type of pharmaceutical formulation applied to the lotion base and the size of the wound used.

In recent years, there was an increasingly growing investigations on the involvement of mast cells in various pathophysiological processes of healing, especially the influence of chemical and physical agents in the population of mast cells ${ }^{17,18}$.

The stimulation of immune cells with mast cell degranulation and consequent release of mediators in the initial phase of the process (inflammatory phase) regulates leukocyte infiltration into the wound ${ }^{11,19}$. In our study we noticed a lower concentration of mast cells, as well as a higher mastcell degranulation in the 4th day of $X$. americana extract treated group. In the proliferative phase, the role of mast cells remains to be elucidated more clearly. Some studies have shown that healing is dependent on histamine release ${ }^{19}$ while others claim that its absence does not influence the wound reepithelialization ${ }^{20}$. Estevão et al. ${ }^{12}$ demonstrated a significant increase in the concentration of mast cells on the 7th postoperative day in skin wounds in rats treated with $10 \%$ aroeira oil lotion, followed by better epithelial contraction.

In the present study, the $X$. americana treated group showed less number of mast cells when compared to the other studied groups. Similar findings were reported by Noli and Crumb ${ }^{21}$, studying the effects of urucum extract in oral wounds. According to these authors, the 
rapid disappearance of perilesional mast cells can be attributed to their degranulation, making it difficult to identify in the histological sections. Wilgus and Wulff ${ }^{19}$ report on a review study that the increase in mast cell degranulation at healing process by second intention may be the cause of persistent of the acute phase for up to one week, indicating that there is maintenance of chemotatic activity in this period. Chen et al. ${ }^{22}$ blocked the degranulation of mast cells in wound repair using cromolyn disodium and observed a reduction in healing time. However, there was no increase in the inflammatory phase in this experiment, which may indicate the modulatory ability of these cells in the healing process. The findings of this study agree with the reports of Rittié ${ }^{23}$ who observed that there is a greater proliferation of fibroblasts on 7th postoperative day, which arise from the second and third day of the beginning of the healing process.

Fibroblasts are very important cells in tissue repair. During the fibroplasia period there is a migration and proliferation of fibroblasts at the site of injury, as well as intensive production of collagen, fibronectin and glycosaminoglycans, which contribute to the formation of granulation tissue; some fibroblasts acquire actin and myosin myofilaments, which perform wound contraction ${ }^{23}$. Collagen production is continuous and growing until about the 21st postoperative, when establishing homeostasis and the degradation rate is balanced with the synthesis ${ }^{24}$. Since angiogenesis is a physiological process that refers to the production of new blood vessels from preexisting, both on growth and development, as well as wound healing and chronic inflammations ${ }^{24}$.

On slides stained with Masson's Trichrome, it was observed high concentrations of collagen fibers in all groups. However, in the group treated with $X$. americana $(\mathrm{GX})$ the fibers were denser in the 4th (PO) and quite organized on the 14th (PO), when compared to the other groups. According with the results found by Carvalho et al. $^{25}$ that by using the aqueous extract of $20 \% X$. americana in skin wounds of mice, significant amounts of collagen fibers were noticed. Voss et al. ${ }^{5}$ also observed an increase in extracellular collagen deposition, concluding that there was effective stem bark extract cream $X$. americana $10 \%$.

\section{- Conclusion}

Buserelin induces apoptotic cell death in spermatozoa lineage and decreases epithelium Thickness of seminiferous tubules in the adult rat testes in addition to disruption cell association in seminiferous tubules.

\section{- References}

1. Almeida $\mathrm{ML}$, Freitas $\mathrm{WE}$, de Morais $\mathrm{PL}$, Sarmento JD, Alves RE. Bioactive compounds and antioxidant potential fruit of Ximenia americana L. Food Chem. 2016;192:107882. doi: 10.1016/j.foodchem.2015.07.129.

2. Maikai VA, Maikai BV, Kobo PI. In vitro effect of aqueous extract and fraction IV portion of Ximenia americana stem bark on Trypanosoma congolense DNA. J Parasitol Res. 2014;2014:904318. doi: 10.1155/2014/904318.

3. Souza RK, da Silva MA, de Menezes IR, Ribeiro DA, Bezerra LR, Souza MM. Ethnopharmacology of medicinal plants of carrasco, northeastern Braz. J Ethnopharmacol. 2014;157:99-104. doi: 10.1016/j.jep.2014.09.001.

4. Soro TY, Traore F, Sakande J. Analgesic activity of the aqueous extract from Ximenia americana. C R Biol. 2009;332(4):371-7. doi: 10.1016/j.crvi.2008.08.022.

5. Voss C, Eyol E, Berger MR. Identification of potent anticancer activity in Ximenia americana aqueous extracts used by African traditional medicine. Toxicol Appl Pharmacol. 2006;211(3):177-87. doi: 10.1096/fj.055231 fje.

6. Asres K, Bucar F, Kartnig T, Witvrouw M, Pannecouque C, De Clercq E. Antiviral activity against human immunodeficiency virus type 1 (HIV-1) and type 2 (HIV-2) 
of ethnobotanically selected Ethiopian medicinal plants. Phytother Res. 2001;15(1):62-9. PMID: 11180526.

7. Koné WM, Atindehou KK, Terreaux C, HostettmannK, Traoré D, Dosso M. Traditional medicine in north Côted'Ivoire: screening of 50 medicinal plants for antibacterial activity. J Ethnopharmacol. 2004;93(1):43-9. doi: 10.1016/j.jep.2004.03.006.

8. Oehmichen M, Gronki T, Meissner C, Anlauf $M$, Schwark T. Mast cell reactivity at the margin of human skin wounds: an early cell marker of wound survival? Forensic Sci Int. 2009;191(1-3):1-5. doi: 10.1016/j. forsciint.2009.05.020.

9. Rizzi A, Crivellato E, Benagiano V, Ribatti D. Mast cells in human digestive tube in normal and pathological conditions. Immunol Lett. 2016;177:16-21. doi: 10.1016/j. imlet.2016.07.002.

10. Nishikori $\mathrm{Y}$, Shiota $\mathrm{N}$, Okunishi $\mathrm{H}$. The role of mast cells in cutaneous wound healing in streptozotocin-induced diabetic mice. Arch Dermatol Res. 2014;306(9):823-35. doi: 10.1007/s00403-014-1496-0.

11. Ng MF. The role of mast cells in wound healing. Int Wound J. 2010;7(1):55-61. doi: 10.1111/j.1742-481X.2009.00651.x.

12. Estevão LR, Medeiros JP, Simões RS, Arantes RM, Rachid MA, Silva RM, Mendonça Fde $S$, Evêncio-Neto J. Mast cell concentration and skin wound contraction in rats treated with Brazilian pepper essential oil (Schinus tere-binthifolius Raddi). Acta Cir Bras. 2015;30(4):289-95. doi: 10.1590/S0102865020150040000008.

13. Pessoa WS, Estevão LR, Simões RS, Barros ME, Mendonça Fde S, Baratella-Evêncio L, Evêncio-Neto J. Effects of angico extract (Anadenanthera colubrina var. cebil) in cutaneous wound healing in rats. Acta Cir Bras. 2012;27(10):655-70. doi: 10.1590/ S0102-86502012001000001.

14. Ramsey DT, Pope ER, Wagner-Mann C, Berg JN, Swaim SF. Effects of three occlusive dressing materials on healing of full- thickness skin wounds in dogs. Am J Vet Res. 1995;56(7):941-9. PMID: 7574165.

15. Darby IA, Zakuan N, Billet F, Desmoulière A. The myofibroblast, a key cell in normal and pathological tissue repair. Cell Mol Life Sci. 2016;73(6):1145-57. doi: 10.1007/s00018015-2110-0.

16. Marinho PVT, Nóbrega-Neto PI, Pedrosa D, Leite ARA, Ramos SML, Dantas AFM, Minto BW. Avaliação do extrato hidroalcoólico de Ximenia americana no processo cicatricial de feridas cutâneas experimentais em caprinos. Vet e Zootec. 2013;20(4):604-14.

17. Barroso PR, Lopes-Rocha R, Pereira EM, Marinho SA, de Miranda JL, Lima NL, Verli FD. Effect of propolis on mast cells in wound healing. Inflammo-pharmacology. 2012;20(5):289-94. doi: 10.1007/s10787011-0105-5.

18. Weller K, Foitzik K, Paus R, Syska W, Maurer M. Mast cells are required for normal healing of skin wounds in mice. FASEB J. 2006;20(13):2366-8. doi: 10.1096/fj.065837 fje.

19. Wilgus TA, Wulff BC. The importance of mast cells in dermal scarring. Adv Wound Care (New Rochelle). 2014;3(4):356-65. doi: 10.1089/wound.2013.0457.

20. Gallant-Behm CL, Hildebrand KA, Hart DA. The mast cell stabilizer ketotifen prevents development of excessive skin wound contraction and fibrosis in red Duroc pigs. Wound Repair Regen. 2008;16(2):226-33. doi: 10.1111/j.1524-475X.2008.00363.x.

21. Noli C, Miolo A. The role of mast cells in the early stages of wound healing. Int Wound J. $2010 ; 7(6): 540$. doi: 10.1111/j.1742481X.2010.00719.x.

22. Chen L, Schrementi ME, Ranzer MJ, Wilgus TA, DiPietro LA. Blockade of mast cell activation reduces cutaneous scar formation. PLoS One. 2014;9(1):e85226. doi: 10.1371/ journal.pone.0085226.

23. Rittié L. Cellular mechanisms of skin repair in humans and other mammals. J Cell Commun 
Signal. 2016;10(2):103-20. doi: 10.1007/ s12079-016-0330-1.

24. Katsouda A, Bibli SI, Pyriochou A, Szabo C, Papapetropoulos $A$. Regulation and role of endogenously produced hydrogen sulfide in angiogenesis. Pharmacol Res. 2016;113(Pt
A):175-85. doi: 10.1016/j.phrs.2016.08.026. 25. Carvalho BE, Silva POHE, Moura PAM, Santos VLZJ. O uso da Ximenia americana L. como cicatrizante de feridas superficiais em Mus musculus. Rev Inter NOVAFAPI. 2009;2(4):33-9.

\section{Correspondence:}

Joaquim Evêncio-Neto

Universidade Federal Rural de Pernambuco/ DMFA

Rua Manoel de Medeiros, s/no Dois Irmãos

52171-900 Recife - PE Brasil

evencio@dmfa.ufrpe.br

Conflict of interest: none

Financial sources: FACEPE, FAPEMIG, and CNPq
Received: Oct 27, 2016

Review: Dec 26, 2016

Accepted: Jan 24, 2017

${ }^{1}$ Research performed at Department of Morphology and Animal Physiology, Universidade Federal Rural de Pernambuco (UFRPE), Recife-PE, Brazil. Part of PhD degree thesis, Postgraduate Program in Animal Bioscience. Tutor: Joaquim Evêncio-Neto. 